\title{
MENINGKATKAN KEMAMPUAN MENGHITUNG PERKALIAN MELALUI METODE JARIMATIKA PADA SISWA KELAS III SDN 106162 KEC. MEDAN ESTATE
}

\author{
Martiana Panjaitan \\ Surel: rusliyeo95@gmail.com.
}

\begin{abstract}
ABSTRAK
Penelitian ini bertujuan untuk mengetahui penerapan strategi pembelajaran Metode Jarimatika dalam memahami Menghitung Perkalian siswa kelas III semester ganjil SD. Neg 106162 Medan Estate dan untuk mengetahui peningkatan prestasi siswa kelas III semester ganjil SD. Neg 106162 Medan Estate dalam memahami Menghitung Perkalian melalui penerapan strategi pembelajaran Metode Jarimatika. Penelitian ini dilaksanakan dengan menggunakan metode kualitatif interaktif dan pendekatan penelitian tindakan kelas PTK (class action research) yang dilakukan dengan 2 siklus. Adapun subyek penelitian tindakan kelas ini adalah siswa kelas III semester ganjil SD. Neg. 106162 Medan Estate. Berdasarkan analisis data dapat disimpulkan bahwa pada siklus 1 ketuntasan belajar siswa pada materi ini nilai rata-rata hanya 60,00 sedangkan pada siklus 2 dengan menerapkan strategi pembelajaran Metode Jarimatika meningkat mencapai nilai rata-rata 85,00. Respon siswa juga meningkat, data hasil observasi terhadap aktivitas siswa dari $62,50 \%$ pada siklus 1, meningkat pada siklus 2 menjadi 91,67\%.
\end{abstract}

Kata Kunci: Kemampuan, Metode, Jarimatika.

\begin{abstract}
This research aims to know the implementation of learning strategies Method of Jarimatika in understanding Counting multiplication grade 3 students of the odd semester of elementary school. Neg 106162 Medan Estate and To know the improvement of achievement of third grade students of odd semester of elementary school. Neg 106162 Medan Estate in understanding Counting Multiplication through the implementation of the Jarimatic Method learning strategy. This research was conducted using qualitative interactive method and class action research classroom research approach with 2 cycles. The subject of this class action research is the third grade students of the odd semester of elementary school. Neg. 106162 Medan Estate. Based on the data analysis can be concluded that in the first cycle of students' learning completeness on this material an average value of only 60.00 while in cycle 2 by applying the Jarimatika Method of learning method increased to an average value of 85.00. Student response also increased, observation data on student activity from $62.50 \%$ in cycle 1, increased in cycle 2 to $91.67 \%$.
\end{abstract}

Keywords: Abilities, Methods, Jarimatika

\section{PENDAHULUAN}

Dalam Undang-undang No. 2 tentang Pendidikan Nasional yang berlaku saat ini ada penjenjangan pendidikan jalur sekolah yaitu pendidikan dasar yang meliputi
Sekolah Dasar dan Sekolah Lanjutan

Tingkat Pertama, pendidikan menengah yang meliputi Sekolah menengah Umum dan Sekolah

Menengah Kejuruan, serta pendidikan tinggi yang merupakan 
jenjang pendidikan jalur sekolah terakhir. Kenyataan menunjukkan

bahwa pelajaran Matematika diberikan di semua sekolah, baik di jenjang pendidikan dasar maupun pendidikan menengah. Soedjadi (2000:3) menyatakan "Matematika yang diberikan di jenjang persekolahan itu sekarang biasa disebut sebagai Matematika sekolah (school mathematics)".

Matematika adalah salah satu pelajaran yang penting di sekolah dasar. Mata pelajaran Matematika telah diperkenalkan sejak siswa menginjak kelas I Sekolah Dasar

(SD). Secara rinci pada Permendiknas nomor 22 tahun 2006 tentang Standar Isi untuk mata

pelajaran Matematika SD/MI dinyatakan bahwa tujuan pembelajaran Matematika di SD adalah:

a. Melatih cara berpikir dan bernalar dalam menarik kesimpulan.

b. Mengembangkan aktivitas kreatif.

c. Mengembangkan kemampuan memecahkan masalah.

d. Mengembangkan kemampuan menyampaikan informasi atau mengkomunikasikan gagasan.

Matematika merupakan salah satu mata pelajaran yang diajarkan di sekolah-sekolah dengan frekuensi jam pelajaran yang lebih banyak dibandingkan dengan mata pelajaran yang lainnya. Namun demikian banyak yang menganggap bahwa

pelajaran Matematika adalah pelajaran yang paling sulit, menakutkan, menjenuhkan dan tidak menyenangkan. Siswa pada umumnya menganggap bahwa mata pelajaran Matematika adalah "momok". Pelajaran yang kerap dihindari seperti kerapnya untuk tidak dipelajari. Berbicara mengenai Matematika itu sulit tentunya tidak lepas dari ketidaksenangan dari peserta didik tentang mata pelajaran Matematika itu sendiri.

Dari hasil analisis ulangan harian yang pernah peneliti lakukan, menemukan setidaknya 5 hal yang mengakibatkan mengapa Matematika sulit. Pertama, pemahaman siswa tentang isi dan maksud soal relatif lemah. Kedua, sebagian siswa tidak bisa mengawali jawaban atau dengan kata lain siswa tidak tahu harus mulai dari mana untuk menemukan jawaban. Ketiga, siswa terkadang lupa dengan aturan-aturan matematis, rumus-rumus dan terkadang terjebak dengan syarat-syarat yang tidak boleh dan harus dipenuhi oleh suatu penyederhanaan kalimat matematika atau suatu persamaan. Keempat, seringnya terjadi kesalahan kalkulasi dalam jawaban siswa yang tentunya mempengaruhi hasil akhir jawaban. Kelima, ada kecenderungan siswa mengerjakan soal dengan satu cara saja, tidak kreatif dalam mencari cara baru.

Berdasarkan hasil wawancara dengan guru, perkalian termasuk topik yang sulit dipahami siswa. Ini dapat dilihat dari hasil ulangan harian tentang operasi hitung perkalian menunjukkan bahwa dari 
34 siswa kelas III SDN 106162Medan Estate yang mendapatkan nilai kriteria ketuntasan minimal (KKM) 70 hanya 9 siswa, sedangkan 25 siswa masih belum memenuhi kriteria ketuntasan minimal yang telah ditentukan. Hal ini dikarenakan dalam menyampaikan konsep perkalian, para guru banyak yang menggunakan cara konvensional yaitu dengan memaksa anak untuk menghafal secara mencongak.

Persoalan matematika yang sering di hadapi anak adalah sering

kali anak kurang terampil mengoperasikan aritmatika. Walaupun mereka mampu, kebanyakan dari mereka kurang cepat dan tepat untuk membantu persoalan mengalikan angka. Peneliti memiliki pengalaman dalam membimbing anak dengan menyampaikan metode hitung perkalian angka dengan jari tangan. Di sinilah kewajiban seorang guru untuk menanamkan rasa senang terhadap materi pelajaran Matematika tentang perkalian dengan memberi rangsangan atau dorongan agar siswa menyenangi pelajaran Matematika.

Materi perkalian diperkenalkan kepada para siswa ketika mereka menginjak kelas III SD. Perkalian dengan hasil bilangan dua angka merupakan kompetensi dasar yang baru bagi peserta didik kelas III SD.

Konsep perkalian ditanamkan sebagai penjumlahan berulang,

sehingga kemampuan dasar berhitung perkalian dua bilangan 1 -
10 seharusnya sudah dikuasai oleh peserta didik kelas III pada semester ganjil, karena penguasaan materi perkalian ini merupakan bekal prasyarat untuk mempelajari materi berhitung selanjutnya.

Di kelas ini, para siswa dituntut untuk segera menghafal perkalian dan pembagian, karena jika tidak segera hafal, anak akan merasa kesulitan jika telah menginjak materi Matematika di kelas berikutnya. Perkalian mungkin memang susah, tapi setidaknya seorang guru bahkan orang tua dapat membuatnya menjadi lebih menyenangkan. Salah satu hal yang bisa membuat anak-anak senang dengan Matematika adalah kebebasan mereka bereksperimen dengan Matematika tersebut.

Saat ini telah berkembang macam-macam metode untuk berhitung. Pada intinya semua metode adalah baik, semua anak berhak untuk mempelajari teknikteknik yang ada, sehingga mereka kaya akan suatu teknik. Salah satu metode yang telah berkembang untuk pembelajaran Matematika khususnya dalam berhitung adalah pengajaran teknik jarimatika. "Jarimatika adalah teknik berhitung mudah dan menyenangkan dengan menggunakan jari-jari tangan". (Septi Peni, 2008: 17). Metode hitung dengan jari tangan yang bertujuan untuk membantu siswa dalam mengoperasikan aritmatika terutama dalam berhitung perkalian.

Tidak hanya guru yang dapat menggunakan teknik Jarimatika ini, akan tetapi orang tua juga dapat 
menggunakannya dalam pembelajaran di rumah. Atas peran guru, orang tua, dan tentunya niat dari siswa, teknik Jarimatika ini diharapkan dapat membantu meningkatkan kemampuan siswa pada mata pelajaran Matematika, terutama dalam berhitung perkalian. Permasalahan pokok yang ingin Peneliti sampaikan dalam penelitian ini berjudul "Meningkatkan Kemampuan Menghitung Perkalian Melalui Metode Jarimatika Pada Siswa Kelas III Semester ganjil SDN 106162 Medan Estate Tahun Pelajaran 2017/2018.

Berdasarkan latar belakang masalah yang telah diuraikan diatas maka dapat diidentifikasikan masalah yang timbul antara lain:

Masih rendahnya ketrampilan berhitung perkalian siswa kelas III SD dan masih kurangnya sosialisasi tentang pembelajaran berhitung matematika menggunakan metode berhitung dengan alat bantu serta Pengaruh ketrampilan berhitung terhadap kemampuan siswa.

Pembatasan masalah diperlukan agar penelitian ini lebih efektif, efisien, terarah dan dapat dikaji. Penelitian ini difokuskan pada hal-hal berikut:

a. Metode berhitung yang digunakan dalam penelitian ini adalah metode jarimatika dengan penggunaan alat bantu jari tangan.

b. Siswa kelas III SDN 106162 Medan Estate tahun pelajaran 2017/2018.
Berdasarkan latar belakang di atas, maka dapat dirumuskan masalah sebagai berikut: "Apakah dengan menggunakan teknik jarimatika dapat meningkatkan kemampuan berhitung perkalian pada siswa kelas III SDN 106162Medan Estate tahun pelajaran 2017/2018?".

Tujuan yang ingin dicapai dalam penelitian ini adalah untuk meningkatkan kemampuan berhitung perkalian dengan menggunakan teknik jarimatika pada siswa kelas III SDN 106162Medan Estate tahun pelajaran 2017/2018.

\section{METODE PENELITIAN}

Tempat yang peneliti jadikan pelaksanaan penelitian tindakan kelas ini adalah di SD Negeri 106162 Kecamatan Medan Estate Tempat penelitian berlokasi di SD Negeri 106162 Kecamatan Medan Estate Kabupaten Deli Serdang, dimana tempat ini sekaligus tempat peneliti melaksanakantugas mengajar. Alasan peneliti memilih tempat tersebut adalah: 1) Lokasinya dekat dengan rumah peneliti sehingga mudah dijangkau, 2) Peneliti saat ini menjadisalah satu guru yang mengajar di sekolah tersebut sehingga memudahkan peneliti

untuk melaksanakan penelitian tindakan kelas ini.

Penelitian tindakan kelas ini dilaksanakan dalam waktu yang cukupsingkat yaitu dalam waktu + Selama 3 bulan yaitu bulan Agustus s/d Oktober 2017. 
Penelitian ini adalah seluruh siswa kelas III SD Negeri106162 Kecamatan Medan Estate Kabupaten Deli Serdang Semester ganjil Tahun Pelajaran 2017/2018 sebanyak 32 siswa. Dalam penelitian ini menggunakan model yang didasarkan atas konsep pokok bahwa penelitian tindakan terdiri dari empat komponen pokok yang juga menunjukkan langkah pelaksanaan penelitian, yaitu: 1 . Perencanaan atau Planning 2. Tindakan atau Acting 3. Pengamatan atau Observasing dan Refleksi atau Reflekting (Arikunto, 2002: 83) Dimana dari empat hal tersebut dapat diilustrasikan dengan bagan gambar berikut:

\section{Siklus I}

Persiapan yang dilakukan untuk proses penelitian tindakan kelas iniadalah mendata seberapa banyak anak yang kesulitas belajar Matematika.

Pada tahap perencanaan, Anak-anak yang akan ditingkatkan Prestasi belajar Matematika dengan menggunakan Metode jarimatika Adapun langkah yang dilakukan pada tahapan ini antara lain:

a. Pengumpulan data diri anak yang Prestasi belajar Matematikanya rendah.

b. Mengidentifikasi masalah yang dihadapi siswa dan memecahkannya.

c. Menyusun Rencana Pelaksanaan Pembelajaran (RPP) yang tepat yakni Metode jarimatika
Selanjutnya, dilakukan Tahapan

Pelaksanaan Tindakan yaitu:

a. Guru menerapkan Metode jarimatika

b. Siswa belajar dalam situasi pembelajaran Matematika dengan Metode jarimatika.

c. Memantau perkembangan Prestasi belajar yang terjadi pada anak.

Pada Tahapan Observasi yaitu tindakan guru memonitor dan membantu siswa jika menemui

kesulitan selama pengajaran Matematika dengan Metode jarimatika.

Mengadakan refleksi dan evaluasi dari kegiatan 1), 2), 3). Berdasarkan hasil refleksi dan evaluasi siklus I dibuat siklus II yang meliputi :

a) Tahap Perencanaan Tindakan

b) Tahap Pelaksanaan Tindakan

c) Tahap Observasi

d) Tahap Refleksi

Tahapan Refleksi Tahapan Rekomendasi yaitu: Tahap ini dilakukan dengan merumuskan tindakan pembelajaran dengan media kongret yang tepat untuk meningkatkan Prestasi belajarMatematika pada siswa kelas III SDN 106162 Kecamatan Medan Estate Kabupaten Deli Serdang.

\section{Siklus II}

Persiapan yang dilakukan untuk proses penelitian tindakan kelas iniadalah mendata seberapa banyak anak yang kesulitas belajar Matematika. 
Martiana Panjaitan : meningkatkan kemampuan menghitung ...

Tahap Perencanaan Tindakan,

yaitu: Anak-anak yang akan ditingkatkan Kemampuan

belajar Matematika dengan

menggunakan Metode jarimatika

Adapun langkah yang dilakukan

pada tahapan ini antara lain:

a. Pengumpulan data diri anak yang Prestasi belajar

Matematikanya rendah.

b. Mengidentifikasi masalah yang dihadapi siswa dan memecahkannya.

c. Menyusun Rencana Pelaksanaan Pembelajaran (RPP) yang tepat yakni Metode jarimatika

Selanjutnya, pada Tahapan Pelaksanaan Tindakan yang dilakukan adalah:

a. Guru menerapkan metode Metode jarimatika

b. Siswa belajar dalam situasi pembelajaran Matematika dengan Metode jarimatika

c. Memantau perkembangan

Prestasi belajar yang terjadi pada anak.

Tindakan guru memonitor dan membantu siswa jika menemuikesulitan selama pengajaran Matematika dengan Metode jarimatika. Mengadakan refleksi dan evaluasi dari kegiatan 1), 2), 3). Berdasarkan hasil refleksi dan evaluasi siklus I dibuat siklus IIyang meliputi :
a) Tahap Perencanaan Tindakan
b) Tahap Pelaksanaan Tindakan
c) Tahap Observasi
d) Tahap Refleksi

5) Tahapan Rekomendasi

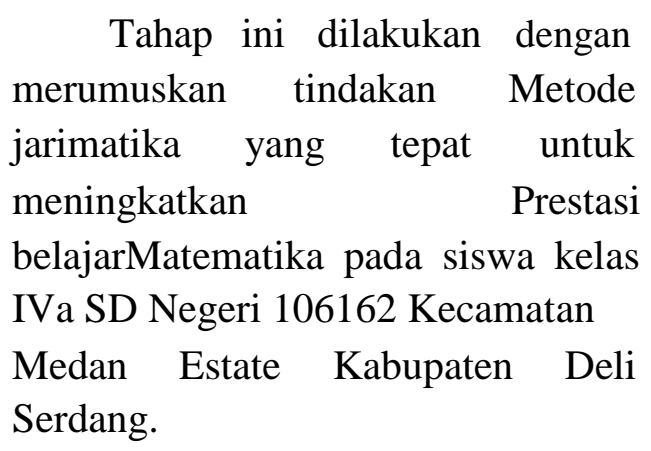

Sumber data penelitian ini adalah:

a. Siswa, untuk mendapatkan data tentang pemahaman siswa

b. Guru, untuk melihat tingkah laku keberhasilan implementasi pembelajaran pemahaman siswa tentang kompetensi

c. Teman sejawat atau Observer, untuk melihat implementasi penelitian tindakan kelas secara komprehensif, baik dari sisi siswa maupun guru.

Pada penelitian ini, pengumpulan data dilakukan dengan menggunakan teknik sebagai berikut:

a. Test awal untuk pengumpulan data awal berkenaan dengan kemampuan siswa terhadap materi.

b. Post Test setelah siswa mengikuti suatu proses perlakuan yang

dilakukan peneliti, guru memberikan soal-soal post test sehingga didapatkan hasil yang akurat dan dapat menggambarkan secara jelas kemampuan awal dan akhir siswa dalam menguasai materi tersebut.

c. Observasi, dengan menggunakan lembarobservasiuntuk 
mengumpulkan data tentang partisipasi dan aktivitas siswa dalam PBM dan implementasi Metode jarimatika

d. Diskusi antara guru, teman sejawat dan Observer, dengan menggunakan lembar pengamatan untuk refleksi hasil siklus PTK.

Alat pengumpulan data dalam penelitian ini adalah:

a. Tes, digunakan untuk mendapatkan data tentang pemahaman siswa berupa tes tertulis menggunakan butir soal/instrumen soal yang telah dirancang oleh peneliti sesuai dengan tujuan yang telah tertuang dalam kisi-kisi soal untuk mengukur pemahaman siswa sebagai hasil belajar siswa.

b. Observasi, untuk mengumpulkan data tentang partisipasi dan aktivitas siswa dalam PBM dan implementasi Metode jarimatika

c. Diskusi antara guru, teman sejawat dan Observer, untuk refleksi hasil siklus PTK.

Data yang diperoleh pada setiap kegiatan observasi dari setiap siklus dianalisis secara deskriftif dengan menggunakan teknik persentase untuk melihat kecenderungan yang terjadi dalam proses pembelajaran. Kegiatan analisis meliputi:

a. Tingkat aktivitas belajar siswa dalam proses pembelajaran, dengan kategori tinggi, sedang dan rendah. b. Tingkat pemahaman siswa berupa nilai dari hasil tes.

c. Tingkat keberhasilan strategi pembelajaran Metode jarimatika dengan kategori berhasil, kurang berhasil dan tidak berhasil.

Analisis data dilakukan dalam suatu proses yang berarti bahwa pelaksanaannya sudah mulai dilakukan sejak pengumpulan data dan dikerjakan secara intensif sesudah meninggalkan lapangan. (Lexi J. Moleong, 1999: 104). Sedangkan teknik yang digunakan adalah teknik analisis data kualitatif yang dikembangkan oleh Miles dan Huberman (1992: 18-19) yang terdiri dari tiga tahap: (1) mereduksi data; (2) menyajikan data; (3) verifikasi dan menarik kesimpulan.

\section{HASIL PENELITIAN DAN PEMBAHASAN}

Penelitian ini dimulai dengan pemberian tes awal yang berfungsi mengukur kemampuan dasar yang dimiliki siswa dan memastikan perlu tidaknya tindakan diberikan pada materi Materi Menghitung Perkalian. Berdasarkan hasil tes awal, diperoleh data sebanyak 29 orang siswa telah memenuhi syarat ketuntasan belajar dan 3 orang belum mencapai nilai ketuntasan belajar.

Dari dua siklus tindakan yang diberikan, dapat dinyatakan bahwa ada peningkatan pemahaman siswa pada Materi Menghitung Perkalian.

Pada aktivitas siswa terjadi peningkatan, pada siklus 1 hanya $62,50 \%$, dan pada siklus 2 meningkat 
menjadi 91,67\%. Pada aktivitas guru juga meningkat, dari $66,67 \%$ pada siklus 1, kemudian meningkat menjadi $88,89 \%$ pada siklus 2 .

Pada Pemahaman siswa pada tes awal hanya $51,82 \%$. Setelah dilakukan tindakan meningkat menjadi $66,00 \%$ pada siklus 1 , kemudian pada siklus 2 mencapai $85,00 \%$. Sesuai dengan indikator kinerja maka penelitian ini telah mencapai nilai aman dan penelitian tidak perlu dilanjutkan lagi.

Perlu diketahui, sampai akhir siklus 2 masih ada nilai 3 orang siswa $(09,38 \%)$ belum mencapai ketuntaan minimal, sehingga diperlukan diberikan perlakuan khusus sehingga nilai siswa tersebut dapat tuntas. Dengan demikian, dari 32 orang siswa, 29 orang siswa $(90,63 \%)$ dinyatakan telah mencapai nilai ketuntasan minimal.

Peningkatan ini jika dilihat dari tindakan yang dilakukan telah sesuai dengan apa yang diharapkan. Selain meningkatkan aktivitas siswa dalam pembelajaran, perasaan senang juga muncul dari siswa. Dan pemahaman siswa menjadi meningkat. Peningkatan ini diyakini sebagai pengaruh penerapan strategi pembelajaran Metode Jarimatika yang dapat meningkatkan daya ingat dan daya nalar siswa.

\section{SIMPULAN}

Berdasarkan hasil penelitian tindakan kelas yang dilaksanakan dalam dua siklus dengan menerapkan teknik jarimatika pada siswa kelas III semester ganjil SDN 106162 Medan
Estate dapat disimpulkan bahwa pembelajaran dengan menggunakan teknik jarimatika dapat meningkatkan kemampuan berhitung perkalian siswa kelas III semester ganjil SDN 106162Medan Estate. Hal ini terbukti pada kondisi awal sebelum dilaksanakan tindakan nilai rata-rata siswa 51,82dengan persentase ketuntasan klasikal sebesar $21,88 \%$, siklus I nilai ratarata kelas 60,00 dengan persentase ketuntasan klasikal sebesar 34,38\% dan siklus II nilai rata-rata kelas meningkat menjadi 85,00 dengan persentase ketuntasan klasikal sebesar 90,63\%. Dengan demikian secara klasikal, pembelajaran telah mencapai ketuntasan belajar.

\section{DAFTAR RUJUKAN}

Arikunto. 2002. Dasar-dasar Evaluasi pembelajaran. Jakarta: Bumi Aksara.

Mulyono, Abdurrahman. 2003. Pendidikan Bagi Anak Berkesulitan Belajar. Jakarta: Depdikbud dan Rineka Cipta.

Nyimas Aisyah, dkk. 2007. Pengembangan Pembelajaran Matematika SD. Jakarta: Dirjen Dikti Drpartemen Pendidikan Nasional.

Hamalik, Oemar. 2009. Proses Belajar Mengajar. Jakarta: Bumi Aksara.

Wulandari, Septi Peni. 2008. Jarimatika Perkalian dan Pembagian. Tangerang: Kawan Pustaka. 
Slameto. 2003. Belajar dan Faktor-

faktor yang Mempengaruhinya.

Jakarta: Rineka Cipta.

Soedjadi. 2000. Kiat Pendidikan

Matematika di Indonesia.

Jakarta: Dirjen Dikti.

Sudjana, Nana. 2005. Dasar-Dasar

Proses Belajar Mengajar.

Bandung: Sinar Baru

Algesindo.

Sudjana, Nana. 2006. Penilaian hasil

Proses Belajar Mengajar.

Bandung: Remaja Rosdakarya.

Suryabrata, Sumadi. 2003. Metode

Penelitian. Jakarta: Rajawali.

Putra, Udin S. Winata. 2007. Strategi

Belajar Mengajar. Jakarta:

Depdikbud. 